\title{
LIBRARIANS COMPETENCE IMPROVEMENT THROUGH OUTBOUND STAFF MOBILITY (OSM) IN INSTITUT TEKNOLOGI SEPULUH NOVEMBER
}

\author{
Lely Indah Mindart*, Anita Triwidiyawati*, \& Tiara Anggiasari* \\ *Universitas Brawijaya \\ Email:lelyfia@ub.ac.id
}

(Submitted: 16-02-2020, Revised: 28-06-2020, Accepted: 12-11-2020)

DOI: $10.24252 /$ kah.v8i2a4

\begin{abstract}
ABSTRAK: Di era disrupsi saat ini, perpustakaan dituntut agar mampu berinovasi dan beradaptasi dengan cepatnya perubahan yang terjadi. Kondisi tersebut direspon oleh Perpustakaan Institut Teknologi Sepuluh November (ITS) Surabaya dengan mengimplementasikan program Outbound Staff Mobility (OSM). OSM pertama kali diinisiasi pada tahun 2013 dan berlanjut hingga sekarang. Penelitian ini menggambarkan implementasi Program OSM di Perpustakaan Institut Teknologi Sepuluh November (ITS) Surabaya guna meningkatkan kompetensi pustakawan. Data penelitian diperoleh melalui wawancara dengan penanggung jawab program OSM, kepala unit perpustakaan ITS, dan pustakawan yang telah lolos dan berhasil berangkat untuk mengikuti program OSM ke luar negeri dari tahun 20132018. Selain itu, data juga diperoleh melalui observasi dan dokumentasi. Analisis data menggunakan model analisis data Creswell. Implementasi program OSM telah berjalan dengan baik, hal tersebut dapat dilihat dari sudah efektifnya kejelasan tujuan yang hendak dicapai, kejelasan strategi pencapaian tujuan, proses analisis dan perumusan kebijakan, perencanaan yang matang, penyusunan program yang tepat, tersedianya sarana dan prasarana, serta tersedianya sistem pengawasan dan pengendalian. Implementasi program OSM juga bisa dikatakan berhasil sebab telah memberikan dampak terhadap peningkatan kompetensi profesionalisme pustakawan, seperti halnya peningkatan wawasan dalam mengelola pelayanan, pemanfaatan teknologi informasi, penyediaan bimbingan dan bantuan, serta manajemen terhadap suatu permasalahan melalui ide kreatif dan inovasi.
\end{abstract}

Kata kunci: Kompetensi pustakawan; Pustakawan perguruan tinggi; Perpustakaan perguruan tinggi; Outbound Staff Mobility

ABSTRACT: In the disruption era, libraries are required to be able to innovate and adapt to rapid changes. This condition was responded to by Institut Teknologi Sepuluh November's (ITS) Library by implementing Outbound Staff Mobility (OSM) program. OSM was first initiated in 2013 and continues till today. The study describes the implementation of OSM at ITS Library in order to improve librarian competence. The data was obtained through interviews with OSM organizers, the head of ITS library, and ITS librarians who have engaged during 2013-2018. In addition, the data were also obtained through observation and documentation. The data analysis used the Creswell data analysis model. OSM program has implemented well. It can be seen from the effectiveness of the clarity of the objectives to be achieved, the clarity of the strategy for achieving objectives, the process of analysis and policy formulation, careful planning, proper programming, the availability of facilities and infrastructure, and the availability of a monitoring system and control. In addition, it has impacted on increasing the professional competence of librarians, such as increasing insight in managing services, utilizing information technology, providing guidance and assistance, and management of problems through creative ideas and innovation.

Keywords: Librarian competency; Academic librarian; Academic library; Outbound Staff Mobility 


\section{PENDAHULUAN}

Peraturan Pemerintah Republik Indonesia Nomor 24 Tahun 2014 tentang Pelaksanaan Undang-Undang Nomor 43 Tahun 2007 tentang Perpustakaan mengamanahkan bahwa perpustakaan merupakan institusi pengelola karya tulis, karya cetak, dan/atau karya rekam secara profesional dengan sistem yang baku guna memenuhi kebutuhan pendidikan, penelitian, pelestarian, informasi, dan rekreasi para pemustaka. Agar masyarakat mampu bertahan dalam menghadapi persaingan era globalisasi, untuk itu diperlukan lembaga ataupun institusi yang mampu dan bisa memberikan informasi yang cukup mengenai perkembangan IPTEK yang telah terjadi. Salah satu lembaga yang tepat dalam memenuhi kebutuhan informasi masyarakat tersebut yaitu perpustakaan.

Perpustakaan perguruan tinggi sebagai salah satu jenis perpustakaan memiliki peranan penting dalam menyediakan berbagai macam sumber informasi dan pengetahuan yang diperlukan untuk menunjang proses kegiatan belajar-mengajar (pendidikan), penelitian dan juga sumber referensi untuk kegiatan pengabdian masyarakat yang dilakukan oleh sivitas akademika (Nurlistiani, 2017). Perpustakaan perguruan tinggi bisa dikatakan mampu mencapai tujuan dan fungsinya dengan baik jika didukung oleh sumber daya manusia (pustakawan) yang berkualitas dan berkompetensi di bidang perpustakaan.

Profesionalisme pustakawan dilihat dari karakteristiknya seperti menjunjung kode etik, memiliki ilmu dan keahlian, mandiri, berkolaborasi, bekerjasama dan selalu berorientasi ke depan (Mustika, 2017). Pustakawan memiliki kompetensi tertentu dalam meningkatkan keprofesionalitasan dan prospek di organisasi atau lembaga tempat bekerja. Perpustakaan untuk mewujudkan keinginan memiliki pustakawan yang berkompetensi tentu tidak bisa didapatkan secara instan.

Perpustakaan Institut Teknologi Sepuluh November (ITS) Surabaya, berkomitmen dalam mewujudkan kualitas pelayanan yang baik melalui implementasi program Outbound Staff Mobility (OSM) yang diselenggarakan oleh International Office ITS (IO-ITS). Program OSM merupakan salah satu kegiatan internship (magang) di berbagai universitas luar negeri yang berada di Malaysia dan Thailand dengan tujuan menginternasionalisasikan tenaga kependidikan (tendik) dan meningkatkan kapasitas/kompetensi sumber daya manusia yang telah ada. Program OSM diperuntukkan kepada para tendik di ITS baik yang berada di fakultas/departemen, perpustakaan, ataupun lembaga lainnya di ITS yang telah lolos melewati tahap administrasi, tahap desk evalution, dan tahap upgrading dengan jangka waktu lama magang selama 7 (tujuh) hari.

Berdasarkan pemaparan di atas, penelitian bertujuan untuk mendeskripsikan dan menganalisis implementasi Program OSM ITS Surabaya serta faktor pendukung dan penghambatnya. Hasil penelitian diharapkan dapat memberikan sumbangsih keilmuan serta memperkaya rujukan dan program pengembangan kompetensi kepustakawan di Indonesia

\section{KAJIAN TERDAHULU}

\section{Administrasi Publik}

Definisi administrasi publik menurut Plano dan Chandler dalam Sjamsuddin (2016: 105), adalah proses dimana sumber daya dan personel publik diorganisir dan dikoordinasikan untuk merumuskan, mengimplementasikan serta mengelola (manage) keputusan-keputusan dalam kebijakan publik. Administrasi publik menurut Henry dalam Pasolong (2008: 19) menjabarkan tentang ruang lingkup administrasi publik yang mencakup tiga aspek, yakni organisasi, manajemen publik serta implementasi. Sehingga dapat dipahami bahwa administrasi publik memiliki kaitan sangat erat dengan implementasi, baik itu tentang implementasi kebijakan maupun implementasinya itu sendiri.

\section{Implementasi Kebijakan}

Pengertian implementasi kebijakan menurut Meter dan Horn dalam Akib (2010:2) merupakan suatu tindakan yang dilakukan oleh organisasi pemerintah maupun swasta secara 
individu maupun secara kelompok yang dimaksudkan untuk mencapai tujuan yang telah ditetapkan sebelumnya. Kebijakan serta program mempunyai hubungan yang sangat erat. Sesuai dengan pembahasan diatas, kebijakan sendiri diartikan sebagai arah sekaligus tindakan yang dilakukan oleh pemerintah untuk mencapai tujuan. Kemudian, program merupakan instrumen kebijakan yang berisi satu atau lebih kegiatan yang dilaksanakan oleh instansi pemerintah/lembaga untuk mencapai tujuan sesuai dengan kebijakan yang telah ditetapkan sebelumnya. Lebih lanjut implementasi kebijakan serta program menurut Jones \& Baird (1991:296), menyatakan bahwa kebijakan merupakan suatu tindakan yang dilakukakan oleh birokrat (pemerintah) melalui peraturan/dasar hukum yang masih bersifat abstrak, kemudian ditindaklanjuti melalui proses transmisi/penjabaran menjadi kegiatan-kegiatan yang jelas salah satunya adalah program.Jadi dapat dipahami bahwa program merupakan instrumen kebijakan yang berisi satu atau lebih kegiatan yang dilaksanakan oleh organisasi untuk mencapai tujuannya.

Jones \& Baird (1991:296) juga memandang implementasi program melalui pendekatan proses, dengan tiga pilar utama, di antaranya:

1) Tahap Pengorganisasian, di mana Jones memandang tahap pengorganisasian sebagai pembentukan atau penataan kembali sumber daya, unit-unit serta metode agar menjadikan program berjalan;

2) Tahap Interpretasi, merupakan usaha untuk mengerti apa yang dimaksud oleh pembentuk kebijakan dan mengetahui benar atau tidak dan bagaimana tujuan akhir itu harus diwujudkan atau direalisasikan;

3) Tahap Pelaksanaan/Aplikasi merupakan penerapan secara rutin dari segala keputusan dan perundang-undangan dengan melakukan kegiatan-kegiatan untuk tercapainya tujuan kebijakan.

Selain itu ada beberapa hambatan dalam implementasi program, Hogwood dan Gunn dalam Purwanto \& Sulistyastuti (2012:14) mengemukakan bahwa pada kenyataannya "perfect implementation" tidak dapat terwujud karena dipengaruhi oleh beberapa faktor baik secara internal maupun eksternal, antara lain; kualitas kebijakan; sumber daya; karakteristik organisasi; komunikasi; koordinasi; kerjasama antar stakeholder; kondisi lingkungan eksternal organisasi seperti sosial, ekonomi, politik; dan yang terakhir adalah dukungan dari sasaran kebijakan (masyarakat).

\section{Pengembangan Kapasitas Sumber Daya Manusia}

Pengembangan kapasitas merupakan suatu upaya inisiatif dalam mengembangkan sumber daya manusia pada umumnya yang berguna untuk guna meningkatkan kapasitas individu agar bisa memenuhi kewajibannya secara profesional maupun meningkatkan kemampuan teknisnya (Grindle, 1980). Pengembangan sumber daya manusia merupakan suatu usaha dalam meningkatkan kemampuan intelektual seorang individu di dalam organisasi untuk menjalankan pekerjaannya dengan lebih baik serta untuk mempersiapkan individu dalam mengemban tanggung jawab organisasi di masa depan yang terus bisa berkembang dan berubah.

\section{Perpustakaan Perguruan Tinggi}

Keberadaan perpustakaan perguruan tinggi sudah didukung dengan adanya Peraturan Menteri Pendidikan dan Kebudayaan Republik Indonesia Nomor 49 Tahun 2014 Tentang Standar Nasional Pendidikan Tinggi pasal 31 ayat (1) yang berisi bahwa perpustakaan menjadi salah satu prasarana yang harus dimiliki perguruan tingggi. Perpustakaan perguruan tinggi menurut Sulistyo-Basuki (2010:73) merupakan perpustakaan yang berada di perguruan tinggi, yang badan bawahannya bersifat struktural maupun lembaga yang berhubungan dengan perguruan tinggi dan mememiliki tujuan utama yaitu mendukung kegiatan tri dharma perguruan tinggi.

Menurut Badan Standardisasi Nasional (2009) menyatakan bahwa perpustakaan perguruan tinggi bertujuan menyediakan akses informasi bagi pengguna untuk kepentingan pendidikan, 
penelitian, dan pengabdian masyarakat.Secara umum tujuan perpustakaan perguruan tinggi menurut Sulistyo-Basuki (2010:74) adalah sebagai berikut: (1) Untuk memenuhi kebutuhan informasi seluruh sivitas akademika seperti dosen, mahasiswa, maupun tenaga administrasi, (2) Menyediakan bahan referensi untuk semua tingkat akademis di perguruan tinggi; (3) Menyediakan tempat belajar yang nyaman untuk pengguna perpustakaan; (4) Menyediakan jasa sirkulasi yang sesuai bagi pengguna; (5) Menyediakan jasa informasi aktif yang tidak terbatas di lingkungan perguruan tinggi akan tetapi juga di lembaga industri lokal. Perpustakaan perguruan tinggi juga memiliki beberapa fungsi menurut Buku Pedoman Perpustakan Perguruan Tinggi (2004: 3), menyebutkan fungsi perpustakaan perguruan tinggi adalah sebagai berikut: (1) Fungsi Edukasi; (2) Fungsi Informasi; (3) Fungsi Riset; (4) Fungsi Rekreasi; (5) Fungsi Publikasi; (6) Fungsi Deposit; dan (7) Fungsi Interpretasi. Selain itu fungsi perpustakaan Perguruan Tinggi menurut Mahmudin (2006: 2) adalah mendukung pelaksanaan Tri Dharma Perguruan Tinggi yang diantaranya menyediakan informasi ilmiah untuk para mahasiswa, dosen, dan staf maupun pengguna dari luar. Baik koleksi buku, majalah, surat kabar, dan jenis koleksi lainnya".

\section{Kompetensi Pustakawan}

Hasugian (2009:137) menjelaskan bahwa pustakawan merupakan seseorang yang bertugas melaksanakan kegiatan perpustakaan untuk memberikan layanan atau jasa bagi pengguna perpustakaan sebagai pencapaain pada misi yang diberikan oleh badan induknya dari pendidikan bidang ilmu perpustakaan, dokumentasi, dan informasi. Lebih lanjut, Azis (2006:44) menyampaikan pendapatnya bahwa pustakawan merupakan ahli perpustakaan. Dengan pengertian tersebut berarti pustakawan sebagai tenaga yang berkompeten dibidang perpustakaan, dokumentasi, dan informasi. Dalam menjalankan tugasnya pustakawan memiliki tugas dan kewajiban yang harus dilakukan. Menurut Hermawan \& Zen (2006:50) menjelaskan bahwa pustakawan memiliki tugas pokok yaitu melaksanakan kegiatan teknis di perpustakaan seperti pengadaan dan pengolahan bahan koleksi serta memberikan pelayanan perpustakaan, menghimpun dan melestarikan serta menyebarkan informasi, memberikan penyuluhan tentang manfaat yang ada diperpustakaan kepada pengguna, mengadakan pameran tentang hasil kegiatan yang ada perpustakaan, serta kemampuan sumber informasi perpustakaan.

Untuk menjalankan tugas dan kewajiban tersebut pustakawan harus memiliki kompetensi. Kompetensi pustakawan merupakan suatu hal yang harus dimiliki berupa kemampuan, pengetahuan, dan keterampilan, sikap, nilai, perilaku, serta karakteristik seorang pustakawan untuk melakukan /melaksanakan pekerjaannya dalam memberikan layanan pada pengguna perpustakaan. Peraturan dari Perpustakaan Nasional dalam Perpustakaan Nasional (2004:227) juga membagi kompetensi pustakawan menjadi 2 bagian yaitu kompetensi profesional dan kompetensi individu/personal. Tujuan dari kompetensi pustakawan itu sendiri adalah kemandirian pustakawan, artinya dengan kemandirian seorang pustakawan akan mampu menciptakan kreatifitas dan inovasi guna menjalankan tugas dan kewajibannya. Sehingga dapat disimpulkan bahwa tujuan dari kompetensi pustakawan yaitu tidak hanya digunakan untuk membantu pustakawan dan kewajibannya, tetapi juga akan mempengaruhi kegiatan - kegiatan manajerial ataupun kegiatan teknis di perpustakaan dengan kemampuan yang telah dimiliki pustakawan.

\section{Magang}

Magang merupakan kegiatan proses pembelajaran yang memuat unsur belajar sambil bekerja. Masalah magang sudah diatur di dalam Undang-undang No. 13 Tahun 2003 tentang Ketenagakerjaan. Selian itu Sudjana (2000:16) berpendapat bahwa magang merupakan salah satu bentuk belajar yang tertua di dunia yang sampai pada era informasi ini masih tetap bertahan keberadaannya. Dengan melakukan magang seseorang yang telah memiliki pengalaman tertentu akan menyampaikan pengetahuan dan keterampilannya kepada orang lain yang belum berpengalaman dan yang lebih dahulu memiliki pengalaman dan keahlian tertentu sehingga pemagang akan memiliki pengalaman ataupun keahlian itu kemudian setelah terjadi penerimaan atau keahlian, pemagang bisa melakukan sendiri. Secara teoritis magang merupakan suatu program yang memiliki pengaruh kuat terhadap sikap kemandirian dan 
keberhasilan kerja. Hal tersebut didukung oleh tujuan magang menurut (Kamil, 2002:12) yaitu sebagai berikut; (1) Untuk menguatkan penguasaan pada ketrampilan yang diinginkan dan ditekuni untuk dijadikan sebagai pekerjaan; (2) Memperluas dan mempercepat jangkauan pengadaan sumberdaya manusia terampil yang cukup mampu untuk berpartisipasi segera dalam proses pembangunan.

\section{METODOLOGI PENELITIAN}

Penelitian ini menggunakan pendekatan kualitatif deskriptif. Penelitian kualitatif adalah penelitian yang mengungkapkan fakta apa adanya tentang suatu objek, gejala, keadaan dengan pencandraan, menggambarkan, menguraikan, mengintepretasikan dalam suatu kesimpulan dan dalam bentuk tulisan yang sistematis (Moleong, 2006). Pengumpulan data dilakukan melalui observasi, wawancara dan dokumentasi. Adapun informan dalam penelitian ini yaitu pegawai dari IO-ITS yang menjadi penanggung jawab program OSM, Kepala unit perpustakaan ITS, dan pustakawan yang telah lolos dan berhasil berangkat untuk mengikuti program OSM ke luar negeri dari tahun 2013-2018. Analisis data menggunakan model analisis data Creswell (2013) yang meliputi pengumpulan data mentah, mengatur dan menyiapkan data analisis, membaca semua data, pengkodean data, tema/deskripsi yang berkaitan, dan menafsirkan makna tema/deskripsi.

\section{HASIL DAN PEMBAHASAN}

\section{Tahap Pengorganisasian}

\section{a) Pelaksana Kebijakan/Program}

Implementasi program Outbound Staff Mobility (OSM) merupakan program yang diselenggarakan oleh International Office ITS (IO-ITS) sejak tahun 2013. Program yang memiliki kegiatan memagangkan tenaga kependidikan yang berada di unit atau departemen ITS ke universitas luar negeri Thailand dan Malaysia guna meningkatkan kapasitas ataupun kompetensi sumber daya manusianya dan mengejar ITS untuk ke WCU. Perpustakaan ITS salah satu unit yang mewakilkan pustakawannya untuk mengikuti program tersebut. Hal tersebut bisa dilihat dari visi perpustakaan yang salah satunya mendukung ITS mencapai WCU.

Tujuan diadakannya program Outbound Staff Mobility (OSM) yaitu; (1) memberikan wawasan dan pengalaman baru kepada tenaga pendidik untuk bekerja secara profesional di tempat kerja yang beragam dengan berstandar internasional; (2) membangun jejaring profesional antara staf non-akademik dari kedua universitas; (3) memperkuat kerjasama antara kedua belah pihak dengan meningkatkan jumlah mobilitas staf. Sehingga tendik ITS mampu memperluas wawasan dan pengalaman mengenai bidang pekerjaannya di level Internasional serta dapat menggali hal-hal inovatif yang dapat diterapkan di ITS.

\section{b) Standart Operating Procedure (SOP)}

Secara khusus Perpustakaan ITS tidak mempunyai aturan /landasan hukum dalam pelaksanaan program OSM, namun kegiatan tersebut dilaksanakan berdasarkan kebutuhan instansi guna meningkatkan kualitas dan kapasitas tenaga pendidik yang bertaran internasional. Terdapat beberapa ketentuan yang berhasil peneliti himpun, terkait persyaratan yang harus dipenuhi oleh peserta agar dapat mengikuti program OSM, antara lain:

a) Persyaratan administrasi

b) Tes Tulis

c) Tes Wawancara

d) Upgrading

Persyaratan tersebut harus dipenuhi, terutama tahapan uprading, dimana upgrading merupakan kegiatan salah satu tahapan seleksi peserta OSM sebelum mereka dinyatakan lolos untuk berangkat magang. Kegiatan yang sifatnya pembelajaran ini dianggap sangat penting sekali guna untuk bekal para tendik magang di luar. Materi yang diberikan pada kegiatan ini 
yaitu mengenai bahasa Inggris, materi kebudayaan, materi mengenai latar belakang ITS, dan materi tentang office.

\section{c) Sumber Daya}

1) Sumber Daya Keuangan/Finansial. Dalam pelaksanaan program Outbound Staff Mobility (OSM) alokasi dana sepenuhnya ditanggung oleh International Office ITS (IO-ITS), dimana alokasi anggaran diperuntukkan bagi peserta yang telah lulus seleksi akan dibiayai pemberangkatan ke luar negeri. Selain itu pihak International Office ITS (IO-ITS) juga menyediakan sedikit alokasi anggaran untuk uang saku bagi peserta yang telah lulus seleksi untuk mengikuti magang ke luar negeri.

2) Sumber Daya Peralatan/Fasilitas. Upaya pemenuhan fasilitas dilakukan oleh International Office ITS untuk mendukung program OSM antara lain seperti penyediaan materi upgrading, pemateri dari dalam dan luar negeri, hingga sarana dan prasarana untuk pemberangkatan peserta OSM ke instansi luar negeri seperti 10 Universitas di Thailand dan 2 Universitas di Malaysia yang telah menjalin kerjasama dengan pihak ITS. Selain itu, untuk pemenuhan fasilitas sarana prasarana yang berupa penginapan dan transportasi bisa disediakan melalui kerjasama dengan pihak kampus tempat magang. Namun, untuk mulai tahun kemarin tidak semua peserta ditanggung oleh IO karena program ini telah dibuka dengan 2 jalur yaitu buttom up dan mandiri.

\section{d) Penetapan Manajemen Pelaksana}

Pelaksanaan program Outbound Staff Mobility (OSM), sepenuhnya di kelola/ manajemen oleh pihak International Office ITS (IO-ITS), dan juga beberapa unit dan departemen di ITS yang akan memberangkatkan peserta untuk ikut program Outbound Staff Mobility (OSM).

\section{e) Penetapan Jadwal Kegiatan}

Pelaksaan program Outbound Staff Mobility (OSM) dilaksanakan pada tiap satu tahun sekali dan telah dimulai sejak 2013 hingga 2019. Dimana kegiatan akan dilakukan dengan beberapa agenda, dimulai dari seleksi administrasi, tes tulis, tes wawancara dan upgrading. Kegiatan upgrading sendiri dilaksanakan pada sore hari sebelum jam kerja berakhir dan kegiatan tersebut dilaksanakan pada durasi 2 jam. Kemudian untuk kegiatan magang internasional dilakukan selama 7 hingga 14 hari.

\section{Tahap Interpretasi}

Tahap interpretasi merupakan tahap penjabaran kebijakan yang masih abstrak menjadi teknis operasional. Terdapat dua agenda pada tahapan ini, antara lain sebagai berikut:

Pertama, transmisi Perintah kepada Para Pelaksana yang dilakukan melalui komunikasi dengan pendekatan berupa instruksi, sosialisasi, dan koordinasi melalui beberapa kegiatan yang terdiri dari himbauan hingga strategi uprading demi meningkatkan kapasitas dan profesionalisme pustakawan agar dapat bersaing dan memberikan pelayanan dengan standart internasional.

Kedua, penyampaian dan Pemahaman Mengenai Tujuan Program sesuai dengan tujuan yang di amanatkan bahwa program Outbound Staff Mobility (OSM) ini dibuat dalam rangka menginternasionalisasikan tenaga pendidik yang dimiliki ITS dan untuk meningkatkan kompetensi ataupun kapasitas mereka. Peningkatan kompetensi profesional pustakawan seperti peningkatan pengetahuan, wawasan, aktifitas perpustakaan, serta mampu dalam penggunaan teknologi informasi. Sehingga kompetensi individu pustakawan dapat meningkat dan hal tersebut bisa dilihat cara kerja mereka dan pola pikir mereka menjadi lebih terbuka dan bisa mengikuti perkembangan jaman yang lebih modern.

\section{Tahap Pelaksanaan/Aplikasi}

Pada tahap pelaksanaan program Outbound Staff Mobility (OSM), pihak International Office ITS (IO-ITS) melaksanakan beberapa agenda kegiatan, dimulai dari seleksi administrasi, tes tulis, tes wawancara hingga kegiatan upgrading bagi peserta yang dinilai lolos ke tahap berikutnya. Di 
dalam kegiatan upgrading, peserta wajib menunjukkan antusias serta kecakapan yang selanjutnya akan menjadi penilaian untuk memperoleh sertifikat dan SK dari rektor untuk memperoleh rekomendasi mengikuti program OSM yakni berupa kegiatan magang internasional. Di dalam tahapan pelaksanaan terdapat dua aspek yang turut mempengaruhi, antara lain;

a) Sikap pelaksana/disposisi, dimana dalam menjalankan program Outbound Staff Mobility (OSM), pihak International Office ITS (IO-ITS) memiliki komitmen yang sangat baik, terbukti dengan keseriusan mereka dalam mempersiapkan peserta OSM sebelum berangkat magang ke luar negeri diberikan bekal materi dengan melakukan kerjasama dengan seseorang yang ahli di bidangnya, seperti pelaksanaan OSM pada tahun 2019 yang menggunakan jasa dari negara Kanada. Selain dari pihak penyelenggara OSM, antusias dan komitmen juga ditunjukkan oleh peserta yang ingin mengikuti program magang ke luar negeri, terbukti dengan keseriusan mereka yang rela membiayai proses kegiatan magang secara mandiri demi meningkatkan kompetensi tenaga pendidik.

b) Policy Output, dimana pada awalnya program OSM tidak memberikan indikator khusus untuk menilai keberhasilan program, namun tingkat keberhasilan/kualitas program dapat dilihat dari beberapa aspek, antara lain;

1) Tenaga pendidik yang telah mengikuti magang sudah banyak melakukan perubahan mulai dari cara mereka bekerja, lebih aktif dalam kegiatan internasional ITS, dan mereka bisa melakukan hal-hal inovatif yang terinspirasi dari tempat magang. Begitupun dengan unit perpustakaan ITS, pustakawannya merasa program tersebut berjalan efektif dalam rangka untuk meningkatkan kompetensi mereka.

2) Peserta yang sudah mengikuti program OSM menjadi tahu dalam hal-hal penggunaan teknologi di perpustakaan seperti pengklasifikasian koleksi bisa menggunakan komputer, penggunaan barcode untuk koleksi jurnal, dan sebagainya.

3) Peningkatan terhadap pengetahuan dan keterampilan mereka dalam berkomunikasi terutama bahasa Inggris menjadi meningkat. Selain itu ada perbedaan antara pustakawan yang belum mengikuti program tersebut dengan pustakawan yang belum mengikuti program tersebut.

4) Cara kerja dan pola pikir peserta yang telah mengikuti program OSM menjadi lebih terbuka dan bisa mengikuti perkembangan jaman yang lebih modern.

\section{Faktor Pendukung dan Penghambat Implementasi Program OSM}

Pengaruh dari faktor pendukung terdiri dari adanya dukungan dari pihak ITS dengan menjalin kerjasama dengan 10 Universitas di Thailand dan 2 Universitaas di Malaysia. Kemudian penyediaan materi dan pemateri ahli baik dari dalam maupun luar negeri. Sedangkan pengaruh dari faktor penghambat terdiri dari, masalah anggaran terkait uang saku peserta OSM yang dinilai kurang, jumlah peserta yang pada awal daftar begitu banyak namun setelah melalui tahap uprading turun, dan masalah yang terakhir adalah jadwal pelaksanaan magang yang dinilai sangat singkat yakni hari

\section{KESIMPULAN}

Implementasi program OSM dinilai sudah cukup berhasil dalam pelaksanaannya. Terdapat tiga tahapan implementasi melalui pendekatan proses dalam implementasi program OSM, yakni tahapan pengorganisasian yang melibatkan pihak International Office ITS (IO-ITS), serta kerjasama dengan 10 Universitas di Thailand dan 2 Universitas di Malaysia, kemudian tahapan interpretasi yang dilaksanakan melalui instruksi, sosialisasi, dan koordinasi melalui beberapa kegiatan upgrading, dan yang terakhir adalah tahapan pelaksanaan yang dapat dinilai berdasarkan sikap para pelaksana dan kualitas policy output. Peningkatan kompetensi tenaga pendidik yang telah mengikuti magang mulai dari cara bekerja, aktif dalam kegiatan internasional ITS, inovatif, berwawasan terhadap penggunaan teknologi di perpustakaan, peningkatan keterampilan dalam berkomunikasi menggunakan bahasa Inggris serta cara kerja 
dan pola pikir peserta yang telah mengikuti program OSM menjadi lebih terbuka dan bisa mengikuti perkembangan jaman yang lebih modern. Dalam pelaksanaannya adapun yang menjadi faktor pendukung, yaitu adanya kerjasama dengan 10 universitas di Thailand dan 2 universitas di Malaysia, serta ketersediaan pemateri yang ahli di bidangnya, sedangkan faktor penghambat yaitu masalah ketidaksiapan anggaran program, ketidaksiapan peserta dalam mengikuti kegiatan magang dan yang terakhir adalah masalah jadwal kegiatan magang diluar negeri yang dinilai cukup singkat yakni hari saja.

\section{DAFTAR PUSTAKA}

Akib, H. (2010). Implementasi kebijakan: Apa, mengapa dan bagaimana. Jurnal Ilmiah Ilmu Administrasi Publik, 1(1), 1-11.

Azis, A. (2006). Pustakawan sebagai Tenaga Profesional di Bidang Perpustakaan, Informasi dan Dokumentasi. JKDMM: Jurnal Kepustakawanan dan Masyarakat Membaca, 22, 39-50.

Badan Standardisasi Nasional. (2009). Standar Nasional Indonesia SNI 7330: 2009 tentang Perpustakaan Perguruan Tinggi. Jakarta: BSN.

Grindle, M. S. (1980). Politics and policy implementation in the Third World. Princeton University Press.

Hasugian, J. (2009). Dasar-Dasar Ilmu Perpustakaan dan Informasi. USUpress.

Hermawan, R., \& Zen, Z. (2006). Etika kepustakawanan: suatu pendekatan terhadap kode etik pustakawan Indonesia. Sagung Seto.

Jones, C. O., \& Baird, D. C. (1991). Pengantar kebijakan publik (public policy). Rajawali.

Kamil, M. (2002). Model Pembelajaran Magang Bagi Peningkatan Kemandirian Warga Belajar: Studi Pada Sentra Industri Kecil Rajutan dan Bordir di Ciamis. UPI Bandung.

Moleong, L. J. (2006). Metodologi Penelitian Kualitatif. Bandung: PT. Remaja. Rosdakarya

Mustika, P. (2017). Profesionalisme Pustakawan. Buletin Perpustakaan, 57, 27-35.

Nurlistiani. (2017). Transformasi Perpustakaan Perguruan Tinggi di Indonesia: Tantangan dan Peluang Perpustakaan Digital Menuju E-Learning, EResearch, dan Information Literacy di Perguruan Tinggi. Prosiding Konferensi Perpustakaan Digital Indonesia Ke-9.

Pasolong, H. (2008). Teori Administrasi Publik. Alfabeta.

Perpustakaan Nasional. (2004). Buku Pedoman Perpustakaan Perguruan tinggi. Perpustakaan Nasional RI.

Purwanto, E. A., \& Sulistyastuti, D. R. (2012). Implementation of Public Policy: Concepts and Applications in Indonesia. Gava Media. Yogyakarta.

Undang-undang No. 13 Tahun 2003 tentang Ketenagakerjaan, (2003).

Peraturan Menteri Pendidikan dan Kebudayaan Republik Indonesia Nomor 49 Tahun 2014 Tentang Standar Nasional Pendidikan Tinggi, (2014).

Peraturan Pemerintah Republik Indonesia Nomor 24 Tahun 2014 tentang Pelaksanaan UndangUndang Nomor 43 Tahun 2007 tentang Perpustakaan, (2014).

Sjamsuddin, S. (2016). Dasar - Dasar Teori dan Administrasi Publik. Intrans Publishing. Sudjana, D. (2000). Strategi Pembelajaran Dalam Pendidikan Luar Sekolah. Nusantara Press.

Sulistyo-Basuki. (2010). Pengantar Ilmu Perpustakaan: Modul Universitas Terbuka. Universitas Terbuka. 